\title{
DOELSTELLINGS IN DIE TERSIÊRE ONDERRIG
}

\section{A Van der Merwe}

\author{
Afdeling Universiteitsonderwysbeplanning, Studente Diensburo \\ Universiteit van Pretoria
}

$\mathbf{W}$ anneer daar oor tersiêre onderwysdoelstellings besin word, moet daar in gedagte gehou word dat die algemene doelstellings van verskeie tipes tersiêre onderwysinstellings wel ooreenkomste toon, maar dat daar ook duidelike verskille, al is dit soms net klemverskille, aan te dui is. ' $n$ Sodanige besinning, naamlik oor tersiêre onderwysdoelstellings, moet dus geskied in die lug van

- die algemene doelstellings van 'n tersiêre onderwysinstelling en

- die doelstellings van 'n bepaalde tipe tersiêre onderwysinstelling, maar ook

- die aard en eise van die eietydse samelewing.

Daar word na die samelewing verwys aangesien die doelstellings van 'n tersiêre onderriginstansie grootliks in terme van die aard en eise van die eietydse samelewing geformuleer word. Die samelewing van ons tyd word byvoorbeeld onder andere deur snelle verandering en pragmatisme gekenmerk wat aan die universiteit daarin geopenbaar word dat toenemende klem op beroepsopleiding gelê word. Agt van die elf fakulteite aan $\mathrm{U} \mathrm{P}$ bied byvoorbeeld voorgraads slegs beroepsgerigte kursusse aan. Dié fakulteite wat nie slegs beroepsgerigte voorgraadse kursusse aanbied nie, toon ook 'n progressiewe vermindering in die aantal studente wat vir algemene of nie-beroepsgerigte kursusse inskryf. Daar is byvoorbeeld oor die laaste paar jaar, wat vele blanke universiteite in die $\mathrm{R} \mathrm{S} \mathrm{A}$ in die geheel betref, ' $\mathrm{n}$ skerp afname in die aantal nuweling-eerstejaarstudente wat vir 'n BSc-graad inskryf. Dit is ook bekend dat daar al minder inskrywings aan U P vir die BA-graad is.

Sonder om hier volledig op die algemene doelstellings (en klemverskille in dié verband) van tersiêre onderwysinstansies in te gaan, word verwys na die gemeenskaplike doelstelling wat hier ter sake is, naamlik die vorming en opleiding van studente. Ook hier word egter klemverskille aangetref in soverre die universiteit byvoorbeeld in dié verband groot klem op 'n wetenskaplike of teoretiese grondslag lê.

Die vorming en opleiding van studente verwerklik sigself in die onderrigfunksie. Tersiêre onderwysinstansies staan deesdae, veral wat sy onderrigtaak betref, sterk onder die soeklig van belanghebbendes in die breë samelewing soos die staat, die belastingbetaler, professionele verenigings, beroepsrade, die student self, sy ouers, ens. Vanweë die onderrigsverantwoordelikheid wat die tersiêre onderwysinstansies het, tesame met die pas genoemde intense belangstelling deur instansies van buite, sal die tersiêre onderwys sigself voortdurend didakties moet verantwoord ten opsigte van sy onderrigfunksie.

In die onderrigsituasie gaan dit om die dosent wat bepaalde vakinhoude (die "wat") aan die hand van sekere onderrigvorme* (die "hoe") aan die student oordra met die bedoeling dat hy moet leer. Die onderwysdoelstellings wentel dus om die leeraktiwiteit van die student. Die sinvolheid van alle menslike handelinge staan in die lig van die doel wat bereik wil word. Die sin of betekenis van die onderwysgebeure is geleë in die onderwysdoelstellings. Indien daar dus nie duidelikheid oor die onderwysdoelstellings bestaan nie, kom die sinvolheid van die onderwyshandelinge onder verdenking. Onderwysdoelstellings is dus die uitgangspunt van die verloop van alle onderwysgebeure en is medebepalend vir alle beslissinge (byvoorbeeld ten opsigte van die besondere onderrigmetode, didaktiese hulpmiddele, seleksie van inhoud, ens.) wat tot 'n verantwoorde onderwyspraktyk moet lei. Dit gaan dus om inhoud ("wat") wat op 'n bepaalde wyse of vorm ("hoe") in die lig van onderwysdoelstellings ("waarvoor") deur die dosent aan die student oorgedra moet word.

In die praktyk is dit weliswaar so dat die dosent wat die inhoud van sy vak betref, grootliks gebind is aan die leerplan soos dit in die jaarboek of elders opgeneem is en hy dus nie voortdurend beslissinge hoef te maak oor die seleksie van die inhoud, in die lig van die algemene doelstellings van die besondere onderwysinstelling en die besondere doelstellings van die vak nie. Die doelstellings spreek egter vir die dosent onmiddellik mee wanneer hy aan die hand van die reeds geselekteerde inhoude wil onderrig: Wat wil hy bereik met die oordra van hierdie inhoud?

Soos hoër op genoem, bepaal die onderwysdoelstellings ook keuses ten opsigte van die vorm van die onderrig. Nou is dit die dringende taak van die dosent om keuses te maak ten opsigte van watter onderrigmetodes, ordeningsbeginsels, ens., hy moet gebruik om die inhoude oor te dra sodat bepaalde doelstellings bereik kan word. Dit sal byvoorbeeld in 'n praktiese opleidingsituasie normaalweg meer sinvol wees om te demonstreer as om van die vertelmetode gebruik te maak.

Die formulering van onderwysdoelstellings is dus onontbeerlik en is 'n voorwaarde vir die doeltreffende en sinvolle verloop van die onderriggebeure. In die algemeen gesproke is die uiteindelike doelstelling dat die student moet leer, of anders gestel, dat hy iets moet kan 
doen wat hy nog nie voorheen kon doen nie. Hierdie aktiwiteit van die student moet vooraf deur die dosent onder woorde gebring word - dit is sy onderwysdoelstellings. Ter wille van die verbesondering van die onderwysdoelstellings, kan drie breë terreine onderskei word waarop dit afgespits moet word.

- Die kognitiewe of verstandelike gebied, wat daardie doelstellings insluit wat te doen het met ken, dink en probleemoplossing.

- Die effektiewe of gevoelmatige gebied, wat daardie doelstellings insluit wat te doen het met die gevoelslewe en die kwaliteit van die verhouding tussen die onderwysdeelgenote.

- Die psigomotoriese gebied, wat daardie doelstellings insluit wat gerig is op die (willekeurige) liggaams- of spierbewegings van die mens.

Elkeen van hierdie gebiede lewer terreine op wat nastrewenswaardige onderwysdoelstellings inhou, maar in hierdie bespreking word daar net na die kognitiewe gebied verwys om aan te toon hoe spesifieke onderwysdoelstellings verbesonder en geformuleer kan word.

Die verstandelike gebied word deur Bloom 1 in ses hoofkategorieë onderverdeel, vanaf dié wat die eenvoudigste onderwysdoelstellings stel tot dié wat die mees komplekse handelinge van studente vereis. In alle gevalle is die moeiliker of komplekser handelinge gebaseer op die verwerkliking van dié wat eenvoudiger is. Die ses hoofkategorieë van die verstandelike gebied is die volgende, en daar word telkens verwys na die handelinge wat uitgevoer moet kan word:

Kennis: Definieer, beskryf, identifiseer, paar af, soek uit, benoem, skets, teken, selekteer, vermeld, ensovoorts.

Begrip: Herlei, onderskei, skat, verduidelik, gee voorbeelde, lei af, omskryf, voorspel, som op, werk uit, ensovoorts.

Toepassing: Bereken, demonstreer, verwerk, bepaal, berei, toon aan, los op, ensovoorts

Analise: Ontleed, differensieer, onderskei, herken, identifiseer,-illustreer, wys uit, selekteer, ensovoorts.

Sintese: Klassifiseer, kombineer, stel saam, komponeer, beplan, ontwerp, ensovoorts.

Evaluering: Waardeer, vergelyk, kritiseer, beskryf, verantwoord, verduidelik, ensovoorts.

Aangesien hierdie kategorieè nie absoluut skeibaar is nie, kan sommige handelinge by meer as een ingedeel word.

Elkeen van hierdie kategorieë word verder in subkategorieë onderverdeel wat ook hiëragies georden is ooreenkomstig die moeilikheidsgraad van die handelinge wat die verwerwing van die betrokke bekwaamhede reflekteer.
Die taak van die dosent is dus om in sy besondere vakgebied sy onderwysdoelstellings te verbesonder en homself ten opsigte van elke onderdeel van die vakinhoud te vra: Wat moet die student aan die hand van hierdie deeltjie van die vakinhoud kan dóén? Moet hy 'n nuwe situasie kan evalueer? Moet hy 'n bepaalde vaardigheid kan verrig? ens. Hierdie duidelike formulering van doelstellings is natuurlik ook noodsaaklik vir sinvolle evaluering van die studente.

In hierdie snel veranderende tydsgewrig sal die tersiêre onderwysdoelstellings steeds teen die agtergrond van die doelstellings van 'n tersiêre onderwysinstelling en in die lig van die eise wat die beroepspraktyk stel, in oènskou geneem en indien nodig aangepas moet word. Waar daar in die toekoms oorwegend en toenemend klem in beroepsopleiding geplaas sal word, sal met die eise van die praktyk dus wel deeglik rekening gehou moet word. 'n Eensydige beklemtoning daarvan kan egter daartoe lei dat die student met bloot 'n stel tegnieke of resepte toegerus word wat nie altyd die fundamentele behoeftes van die praktyk bevredig nie. Die deeglike vorming van die student aan die hand van 'n wetenskaplik verantwoordbare teorie oor die praktyk, sal dus nie verwaarloos mag word nie.

Samevattend word die volgende opmerkings oor tersiêre onderwysdoelstellings gemaak:

1. Dit bepaal die verloop van die onderwysgebeure en is dus normatief van aard.

2. Dit bring die student tot sinbelewing; die belewing van die sinvolheid van die vakinhoud is ' $n$ voorwaarde vir sinvolle leer.

3. Dit is beslissend by die seleksie en ordening van die vakinhoudelike.

4. Dit is bepalend vir lesbeplanning, byvoorbeeld by die keuse van onderrigmetodes en -hulpmiddels.

5. Dit is 'n weerspieëling van die leereffek, van wat met die studente bereik wil word, van wat hulle "moet kan doen".

6. Dit is 'n voorwaarde vir sinvolle toetsing en eksaminering.

Bibliografie

Bloom, B.S. 1966 en 1974: Taxonomy of educational objectives; the classification of educational goals, New York, David McKay.

*Onderrigvorme dui op sake soos onderwysmetodes. 